\title{
TOY MODEL OF THE NUCLEON-NUCLEON POTENTIAL
}

\author{
G.P. Kamuntavičius, A. Mašalaitė, and S. Mickevičius \\ Vytautas Magnus University, Vileikos 8, LT-44404 Kaunas, Lithuania \\ E-mail: s.mickevicius@gmf.vdu.lt
}

Received 21 September 2006

\begin{abstract}
We study the simplest quark model, assuming that the sea of gluons and quark-antiquark pairs could be treated as part of a static force, and proceed to calculate the hadronic states by solving the Schrödinger equation for a static confining interaction. We refer to this model starting from a system of six interacting constituent quarks and examine how the picture of two structureless nucleons can change when the effects caused by the substructure of the nucleons are taken into account.
\end{abstract}

Keywords: nonrelativistic quark model, nucleon-nucleon interactions, nuclear forces in vacuum

PACS: $12.39 . J h, 13.75 . \mathrm{Cs}, 21.30 . \mathrm{Cb}$

\section{Introduction}

One of the fundamental goals of nuclear theory is to explain the properties of atomic nuclei in terms of the elementary interactions between pointlike nucleons. By construction, nucleon-nucleon $(\mathrm{NN})$ potentials must first of all reproduce the two-nucleon scattering data and the properties of the deuteron. Recently, progress has been made not only in the phase-shift analysis, but also in the accuracy and consistency of the fits of realistic NN potentials to these data. As a result, several charge-dependent $\mathrm{NN}$ potentials have been constructed, which give a very reasonable fit to the energydependent partial-wave analyses of the NN scattering and produce very good description of deuteron and these $\mathrm{NN}$ data below $350 \mathrm{MeV}$. Potentials like the recent Nijmegen (Nijm I, Reid93, and Nijm II) [1], the Argonne (AV18) [2], and the CD Bonn [3] ones yield a $\chi^{2} /$ datum of about 1 and may be called phase-shift equivalent. Moreover, the potentials Reid93, Nijm II, and AV18 are local potentials. These potentials enjoy great popularity, because they are easy to apply in configuration-space calculations. As such, they are the best candidates for $\mathrm{NN}$ potentials to use in calculations of nuclei having more than two nucleons.

Unfortunately, good $\mathrm{NN}$ potentials, defined as above, can not reproduce even the binding energy of the threenucleon systems. All local realistic NN forces underbind the triton by some $0.8 \mathrm{MeV}$. Similarly, the $\alpha$ particle and the lightest nuclei (with $A \leq 7$ ), for which more or less accurate solutions of the Schrödinger equation can be performed, are all underbound by these potentials. So far, a few different ways for solving this discrepancy have been presented and investigated. They rely on (i) the relativistic corrections, (ii) a nonlocal NN potential, (iii) three-nucleon forces, and (iv) the structure of nucleons taken into account.

Let us briefly summarize the main results of these modifications. Fully relativistic calculations are extremely complicated and consequently have not yet been carried out. The kinematical corrections, yielding a Hamiltonian with the correct transformation properties up to order $(v / c)^{2}$, produce results that are small and repulsive: approximately $0.3 \mathrm{MeV}$ of repulsion in the triton and almost $2 \mathrm{MeV}$ in the $\alpha$ particle [4] (see, however, [5]). Nonlocal NN potentials, such as the CD Bonn, can improve the result for the binding energy of the triton by some $0.4 \mathrm{MeV}$, but not more [6]. The most impressive results for solving the problem of underbinding are obtained by applying phenomenological three-nucleon forces adjusted to achieve the correct triton ground state energy [7]. With this addition ${ }^{4} \mathrm{He}$ is properly bound, while the ground state energies of $A=5-8$ and the excitation energies of the low-lying states are again too high [8].

Many studies have been devoted so far to the understanding of the $\mathrm{NN}$ interaction starting from quark models. A systematic connection to quantum chromodynamics is established by chiral effective field theory. Up to now the two-nucleon system has been considered in chiral perturbation theory $[9,10]$. However, due to the formidable mathematical problems, we are 
still far from a quantitative understanding of the NN force from this point of view. Nevertheless, the success of the pointlike constituent quark model in barion spectroscopy demonstrates that successful application of this approach for two nucleons could be the best chance to understand peculiarities of this interaction and to solve the problem how a NN potential modifies in nuclei due to presence of surrounding nucleons. Let us refer to the simplest quark model, starting from a system of six constituent quarks, and examine now how the picture of two structureless nucleons can change when the effects caused by the substructure of the interacting nucleons are taken into account.

\section{Confining wells of the two-nucleon system}

The picture of structureless nucleons keeping individuality in bound state of two nucleons (deuteron) and scattering states up to $350 \mathrm{MeV}$, so successful for realistic potentials definition, is in essence not consistent with any known scenario with six interacting quarks involved into play. The models based on one-gluon exchange between quarks can explain only the shortrange repulsion of the NN potential. The middle and long-range attraction is obtained from the meson exchange between quarks [11]. The way to get a solution is a nontraditional consideration of problems with confinement in the case when two nucleons approach one another. As it is well known, the established low energy spectrum of quantum chromodynamics behaves as though hadrons are dominated by their valence quark structure and confinement. Also, from the point of view of quarks all nuclei are confined, too. The problem is how the idea of quarks confined in nucleons can be applied for nuclei. Let us assume the quarks are trapped in nucleons by an infinitely deep confining harmonic oscillator (HO) potential, as it is often used in the Standard Model. When nucleons approach each other, the first nucleon confinement potential comes into contact with the corresponding potential of the second nucleon. Let us for the sake of simplicity start the consideration with one-dimensional harmonic confining wells for quarks with a point of contact at $z=0$. Nucleons are identical, so these confinement potentials are symmetrical. Let the bottoms of wells be situated at points $z_{0}$ and $-z_{0}$ respectively. The essential and original our suggestion is that then, in the case when nucleons go into contact, the overlapping confining wells must vanish. An example of such a potential corresponding to $z_{0}=1$ is given in Fig. 1 .

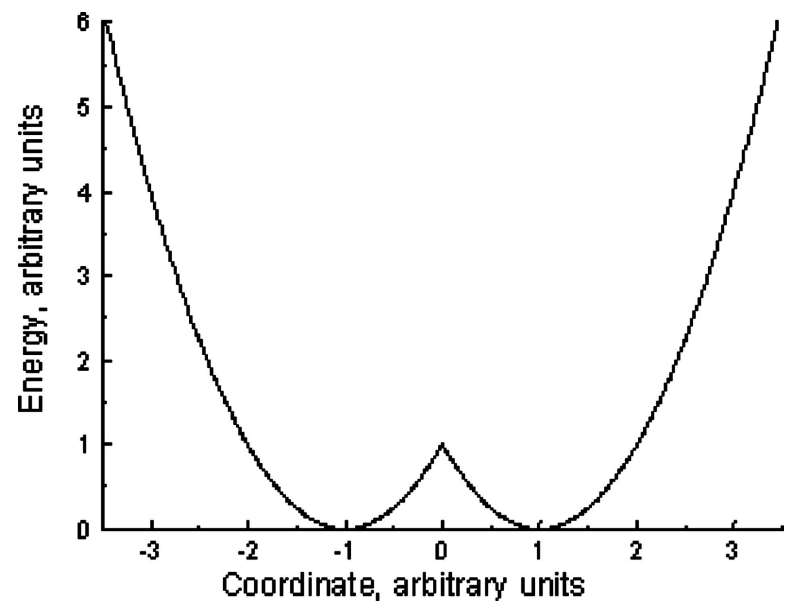

Fig. 1. Confinement potential for two nucleons.

The left-hand branch of this potential well can be expressed analytically as $V(z)=m \omega^{2}\left(z+z_{0}\right)^{2} / 2$, where $m$ is the quark mass (taken equal to $1 / 3$ of the nucleon mass) and $\omega$ is the HO frequency. In the same way the right-hand branch of the potential is $V(z)=m \omega^{2}\left(z-z_{0}\right)^{2} / 2$. Applying the Heaviside function

$$
\Theta(z)=\left\{\begin{array}{l}
0, z<0, \\
\frac{1}{2}, z=0, \\
1, z>0,
\end{array}\right.
$$

one can define analytical expression for the potential from Fig. 1 as

$$
V(z)=\frac{m \omega^{2}\left[\left(z-z_{0}\right)^{2} \Theta(z)+\left(z+z_{0}\right)^{2} \Theta(-z)\right]}{2},
$$

or

$$
V(z)=\frac{m \omega^{2}\left(|z|-z_{0}\right)^{2}}{2} .
$$

The Hamiltonian for a quark moving in this well is given by

$$
H(z)=-\frac{\hbar^{2}}{2 m} \frac{\mathrm{d}^{2}}{\mathrm{~d} z^{2}} \frac{m \omega^{2}\left(|z|-z_{0}\right)^{2}}{2} .
$$

Thus far one has considered one-dimensional confinement potential, while quarks in nucleons move in the three-dimensional well. The three-dimensional Schrödinger equation for constituent quark is

$$
\begin{aligned}
{\left[-\frac{\hbar^{2}}{2 m} \Delta_{\boldsymbol{r}}\right.} & +\frac{m \omega^{2}}{2}\left(\boldsymbol{r}-\boldsymbol{r}_{0}\right)^{2} \Theta(z) \\
& \left.+\frac{m \omega^{2}}{2}\left(\boldsymbol{r}+\boldsymbol{r}_{0}\right)^{2} \Theta(-z)-E\right] \Psi(\boldsymbol{r})=0 .
\end{aligned}
$$


Let us introduce the dimensionless variables and rewrite the Hamiltonian as

$$
\begin{aligned}
{\left[-\Delta_{r}\right.} & +\left(\boldsymbol{r}-\boldsymbol{r}_{0}\right)^{2} \Theta(z) \\
& \left.+\left(\boldsymbol{r}+\boldsymbol{r}_{0}\right)^{2} \Theta(-z)-E\right] \Psi(\boldsymbol{r})=0 .
\end{aligned}
$$

Here dimensionless coordinates are given in terms of oscillator length parameter $b$ and energy is given in corresponding energy quanta $\hbar \omega$. Since $\hbar \omega \cdot b^{2}=\hbar^{2} / m$, the constituent quark mass $m$, equal to one third of the nucleon mass ( $m=m_{\text {nucleon }} / 3$ ), defines the relation of both parameters introduced: $\hbar \omega \cdot b^{2}=125 \mathrm{MeV} \mathrm{fm}^{2}$.

Taking centres of confining wells for nucleons at points $\left(0,0, z_{0}\right)$ and $\left(0,0,-z_{0}\right)$ one can simplify the confining potentials due to relations

$$
\left(\boldsymbol{r}-\boldsymbol{r}_{0}\right)^{2}=x^{2}+y^{2}+\left(z-z_{0}\right)^{2}
$$

and

$$
\left(\boldsymbol{r}+\boldsymbol{r}_{0}\right)^{2}=x^{2}+y^{2}+\left(z+z_{0}\right)^{2} .
$$

Obviously, the wells overlap and vanish on the $(x, y)$ plane of introduced coordinate system, hence one can present Eq. (6) in the form

$$
\begin{gathered}
{\left[-\frac{\mathrm{d}^{2}}{\mathrm{~d} x^{2}}+x^{2}-\frac{\mathrm{d}^{2}}{\mathrm{~d} y^{2}}+y^{2}-\frac{\mathrm{d}^{2}}{\mathrm{~d} z^{2}}+\left(z-z_{0}\right)^{2} \Theta(z)\right.} \\
\left.+\left(z+z_{0}\right)^{2} \Theta(-z)-E\right] \Psi(x, y, z)=0
\end{gathered}
$$

So, the variables in the Schrödinger equation can be separated and it is enough to consider the onedimensional potential along the $z$ axis, i.e. along the line connecting centres of mass of interacting nucleons.

The eigenvalues and eigenfunctions of corresponding one-dimensional Hamiltonians in separate confining wells are

$$
E_{n}=n+\frac{1}{2}, \quad \Psi_{n}(z)=\sqrt{\frac{1}{2^{n} n ! \sqrt{\pi}}} H_{n}(z) \mathrm{e}^{-z^{2} / 2},
$$

where $H_{n}(z)$ are Hermite polynomials of $n$th order. So, the eigenfunctions of Hamiltonian with a well on the left-hand branch of a graph in Fig. 1 are

$$
\Psi_{n}\left(z+z_{0}\right)=\sqrt{\frac{1}{2^{n} n ! \sqrt{\pi}}} H_{n}\left(z+z_{0}\right) \mathrm{e}^{-\left(z+z_{0}\right)^{2} / 2},
$$

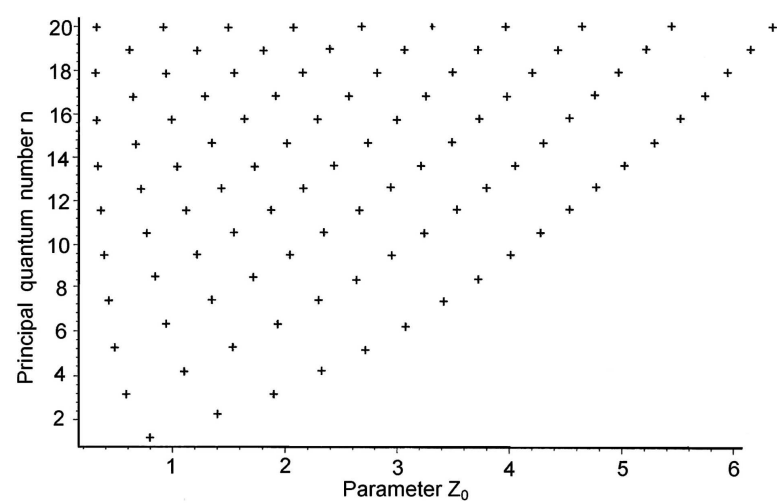

Fig. 2. Values of the oscillator quantum number $n$ versus parameter $z_{0}$ at which the wave functions $\Psi_{n}\left(z_{0}\right)=\Psi_{n}\left(-z_{0}\right)=0$ and derivatives of these functions satisfy the continuity condition (14).

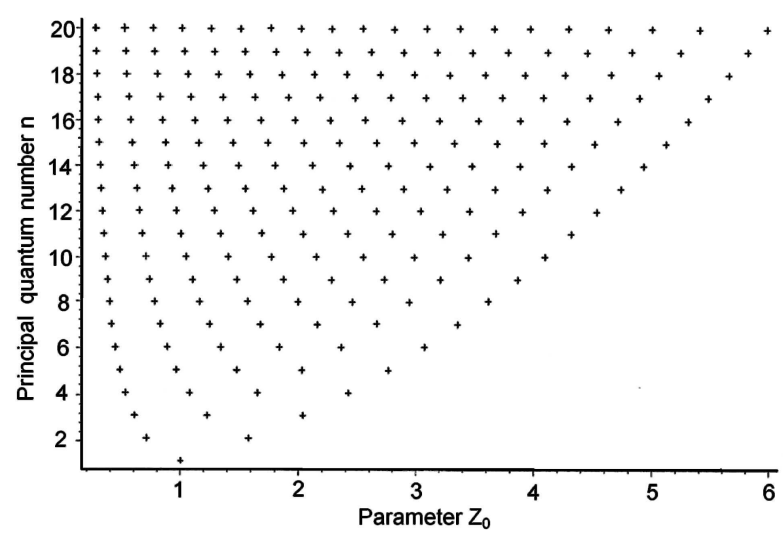

Fig. 3. Values of the oscillator quantum number $n$ versus parameter $z_{0}$ at which the wave functions satisfy the continuity condition (13) and derivatives of these functions $\Psi_{n}^{\prime}\left(z_{0}\right)=\Psi_{n}^{\prime}\left(-z_{0}\right)=0$.

and the corresponding right-hand branch eigenfunctions are

$$
\Psi_{n}\left(z-z_{0}\right)=\sqrt{\frac{1}{2^{n} n ! \sqrt{\pi}}} H_{n}\left(z-z_{0}\right) \mathrm{e}^{-\left(z-z_{0}\right)^{2} / 2} .
$$

Solutions of the Schrödinger equation in the joint confining well exist when eigenfunctions (11) and (12) and their derivatives satisfy the continuity conditions at point $z=0$ :

$$
\left.\Psi_{n}\left(z-z_{0}\right)\right|_{z=0}=\left.\Psi_{n}\left(z+z_{0}\right)\right|_{z=0}
$$

and

$$
\left.\Psi_{n}^{\prime}\left(z-z_{0}\right)\right|_{z=0}=\left.\Psi_{n}^{\prime}\left(z+z_{0}\right)\right|_{z=0} .
$$

It is these conditions for wave functions that give the quantization of spectrum in joint confining well as a function of parameter $z_{0}$. The values of oscillator quanta $n$ versus parameter $z_{0}$, at which the wave functions satisfy conditions (13) and (14), are given in Figs. 2 and 3. 


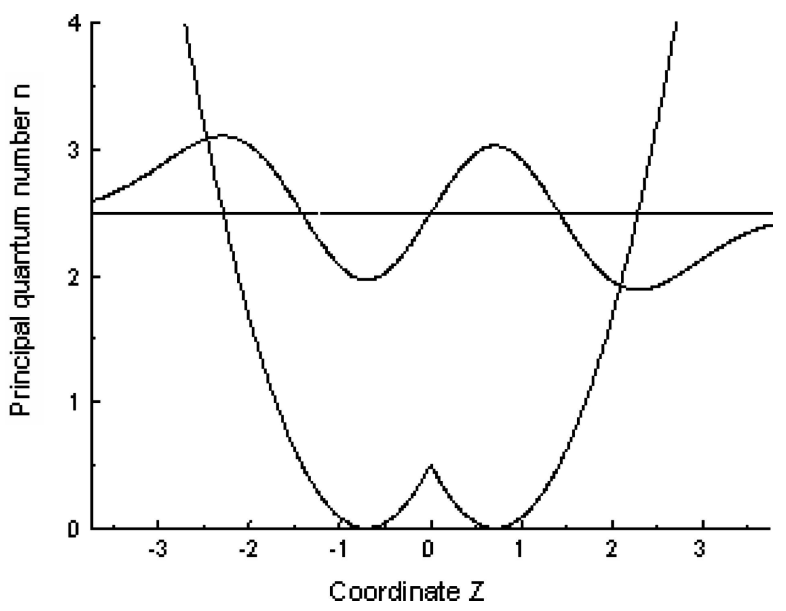

Fig. 4. An example of the wave function antisymmetrical in joint confining well.

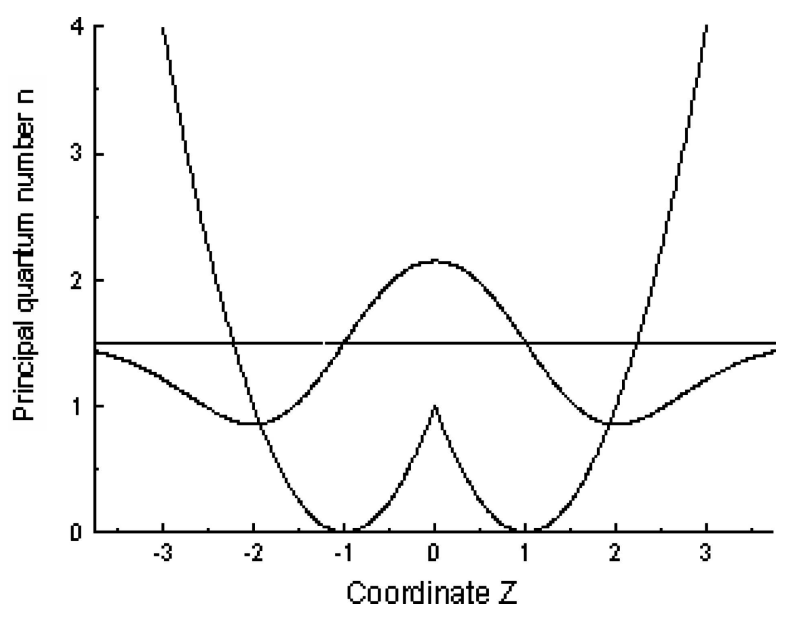

Fig. 5. An example of the wave function symmetrical in joint confining well.

Let us demonstrate some wave functions matching these conditions. As mentioned, the principal quantum number $n$ gives the number of zeros of the corresponding wave function in its own (separate) confining well. Even values of this quantum number correspond to functions symmetrical in their own well, and odd values to functions antisymmetrical in this well. Eigenfunctions of joint well Hamiltonian, symmetrical as well as antisymmetrical, can be composed of functions both symmetrical and antisymmetrical in their own wells. The functions antisymmetrical in joint well are equal to zero at the centre of well, i. e. at point $z=0$ (Fig. 2); symmetrical functions have local maximum or local minimum (zero derivative) at this point (Fig. 3).

Examples of the wave functions, both antisymmetrical and symmetrical in joint confining wells, are shown correspondingly in Figs. 4 and 5. The energy of a bound state in joint confining well is indicated by a

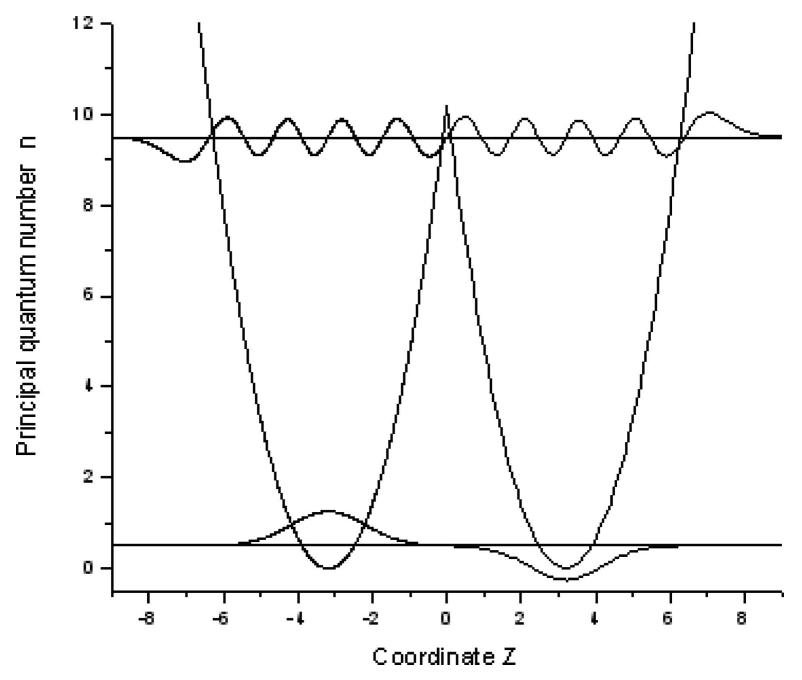

Fig. 6. An example of two lowest levels in joint well. The level $n=$ 0 is approximate level and represents quarks from two separated nucleons. The level $n=9$ is exact level and represents excited quark state.

horizontal line. This line serves as zero line for wave function presented in a figure.

As one may see in presented figures, at any small, not equal to zero $z_{0}$ value, the ground state of this joint confining well is situated at a very high energy. At growing $z_{0}$ the ground state in the well moves down. At some value of $z_{0}$ it reaches minimal value and starts moving up. Finally, at some value of $z_{0}$ there appears the possibility for quarks from two separated nucleons to occupy the Standard Model states $n=0$ in different confining wells. By the way, this function is not an exact eigenfunction for this joint well, but the overlap of functions from different wells is negligible, so from quantum mechanical point of view these states are allowed. When $z_{0}=3.19$, two lowest levels in joint well are $n=9$ (exact level), and $n=0$ (approximate level), shown in Fig. 6.

Let us estimate the parameters of the model. The relation between $b$ and the nucleon radius is $\sqrt{3 / 2} b=$ $0.8 \mathrm{fm}$. This gives $b=0.65 \mathrm{fm}$. This value is close to the value for this parameter in the nonrelativistic quark model, equal to $0.5 \mathrm{fm}$. The distance between centres of nucleons, corresponding to the attraction, is equal to $2 z_{0} b=1.4 \mathrm{fm}$ (Fig. 2). This value is very close to a distance at which a bottom of the potential well of local realistic potentials is situated. The corresponding value for $\mathrm{HO}$ energy quantum is $\hbar \omega=\frac{125 \mathrm{MeV} \mathrm{fm}^{2}}{(0.65 \mathrm{fm})^{2}}=$ $292.96 \mathrm{MeV}$. It approximately equals the energy of two pions, the exchange of which is responsible for interaction between nucleons in the area at a bottom of the potential well. 


\section{Conclusions}

An oversimplified model of two nucleon interaction, based on confining wells for considering quarks of different nucleons, is introduced. The merging of the confining wells, when two nucleons enter the interaction region, excites the six quark system, thus providing the short-range repulsion necessary to reproduce the experimental data without any need of constituent quark Pauli principle and one-gluon exchange taken into account. To some extent it corresponds to "quark soap" scenario. Not a single individual nucleon is obtainable at these distances. At large values of $z_{0}$ the situation changes and there appears the possibility of some individualization of clusters (nucleons) in six quark system. So, the introduced modification of confinement potential in six quark system is well consistent with characteristic features of realistic potentials of NN interaction (core, attraction region, and asymptotic part) and gives the possibility for modification of NN potential, when interacting nucleons are surrounded by additional (spectator) nucleons, i. e. when they are in nuclei.

\section{References}

[1] V.G.J. Stocks, R.A.M. Klomp, C.P.F. Terheggen, and J.J. de Swart, Construction of high-quality NN potential models, Phys. Rev. C 49, 2950 (1994).
[2] R.B. Wiringa, V.G.J. Stocks, and R. Schavilla, Accurate nucleon-nucleon potential with chargeindependence breaking, Phys. Rev. C 51, 38 (1995).

[3] R. Machleidt, F. Sammaruca, and Y. Song, Nonlocal nature of nuclear force and its impact of nuclear structure, Phys. Rev. C 53, R1483 (1996).

[4] J.L. Forest, V.R. Pandharipande, and A. Ariaga, Quantum Monte Carlo studies of relativistic effects in light nuclei, Phys. Rev. C 60, 014002 (1999).

[5] O. Plohl, C. Fuchs, and E.N.E. van Dalen, Modelindependent study of the Dirac structure of the nucleon-nucleon interaction, Phys. Rev. C 73, 014003 (2006).

[6] H. Kamada, A. Nogga, W. Glöckle et al., Benchmark test calculation of four-nucleon bound state, Phys. Rev. C 64, 044001 (2001).

[7] J.L. Friar, G.L. Payne, and U. van Kolck, Chargesymetry-breaking three-nucleon forces, Phys. Rev. C 71, 024003 (2005).

[8] S.C. Pieper, R.B. Wiringa, and J. Carlson, Quantum Monte Carlo calculations of excited states in $A=6-8$ nuclei, Phys. Rev. C 70, 054325 (2004).

[9] M.J. Savage, Effective field theory for nuclear physics, Nucl. Phys. A 721, 94 (2003).

[10] P.A.M. Guichon and A.W. Thomas, Quark structure and nuclear effective forces, Phys. Rev. Lett. 93, 13 (2004).

[11] D. Bartz and Fl. Stancu, Nucleon-nucleon scattering in a chiral constituent quark model, Phys. Rev. C 63, 034001 (2001).

\title{
SUPAPRASTINTAS DVIEJŲ NUKLEONŲ SĄVEIKOS POTENCIALO MODELIS
}

\author{
G.P. Kamuntavičius, A. Mašalaitè, S. Mickevičius \\ Vytauto Didžiojo universitetas, Kaunas, Lietuva
}

\begin{abstract}
Santrauka
Per pastarajji dešimtmetị atomo branduolio teorijoje pasiekta didelè pažanga, kurios pagrindiniai dėmenys yra aukštos kokybės dviejų nukleonu $(\mathrm{NN})$ sąveikos potencialai ir galimybè gauti didelio tikslumo lengviausiųjų branduolių bangines funkcijas, naudojant šiuos potencialus. Naudojant tokius potencialus atkuriami sklaidos duomenys beveik tokiu pat tikslumu, kokiu jie yra išmatuojami eksperimentuose.

Tačiau realistiniai potencialai, kuriais idealiai apibūdinamos dviejų nukleonu sistemos savybès, pasirodè netinkami aprašyti bent kiek sudètingesnių branduolių savybes. Pradedant jau nuo
\end{abstract}

trijų nukleonų branduolių, apskaičiuota nukleonų sistemos ryšio energija bet kuriam minètų potencialų yra maždaug $10 \%$ mažesnè, nei žinoma iš eksperimentų. Tai yra pagrindinis, bet ne vienintelis šių potencialų trūkumas, nes, skaičiuojant naudojantis gautomis banginèmis funkcijomis kitus tuos branduolius apibūdinančius dydžius, gaunami taip pat nepatenkinami rezultatai. Tokios eilès paklaidos gal būtu ir priimtinos aprašant kitokias sistemas, bet atomų branduoliams gauti tokie rezultatai labai iškraipo jų stabilumo įvairių skilimų atžvilgiu vaizdus, todèl šiuo požiūriu yra visiškai nepriimtini.

Pasinaudojant standartiniu elementariųu dalelių fizikos modeliu, išnagrinèta dviejų nukleonų sąveikos atkūrimo problema. 